Chemica

Volume 3, Nomor 2, Desember 2016, 39-45

ISSN: 2355-8776

\title{
Optimasi Pengambilan Antosianin dari Kulit Buah Naga Merah (Hylocereus polyrhizus) Sebagai Pewarna Alami pada Makanan
}

\author{
Ratna Sri Harjanti \\ Program Studi Teknik Kimia, Politeknik LPP \\ Email: ratna_sh@politeknik-lpp.ac.id
}

\begin{abstract}
The addition of synthetic colors in foods in an attempt to attract the attention of consumers, not a ban, but if the dye used is a dye that is unusual for the food, it is harmful to health. One source of natural pigments that can be used is the red dragon fruit skin. These skins contain anthocyanins potential as a dye.

This research observed water content and powder size of the extracted red dragon fruit skin. It was also conducted a stirring speed variation during the extraction process. While the temperature, time, and solvent variables refer to the findings of the previous research. Analysis of the results was conducted to determine $\mathrm{pH}$, anthocyanin concentration and yield results.

Based on the results obtained, the smaller the water content in the skin, the absorbance values are higher. This shows that extractable anthocyanins levels are also higher. The lowest levels of the skin can be achieved in this study was 6\%. The smaller the grain size, the higher the anthocyanin content was obtained. The smallest grain size achieved was 100 mesh. The highest mixing speed in this study was 300 rpm, the higher the stirring speed, the higher the anthocyanin content fetched.

Organoleptic tests were conducted to study the effect of anthocyanins on the quality of the food. It shows that the addition of anthocyanins to color food generates appropriate color and do not significantly affect flavor and aroma. So it can be used as a natural dye for food.
\end{abstract}

Keywords: red dragon fruit, extraction, moisture

\section{Pendahuluan}

Pewarna telah lama digunakan pada bahan makanan dan minuman untuk memperbaiki tampilan produk pangan. Selain untuk produk pangan, pewarna juga digunakan di dalam industri tekstil, kosmetik, peralatan rumah tangga, dan industri lainnya. Pada awalnya zat warna yang digunakan adalah zat warna alami dari tumbuhan dan hewan. Semakin berkembangnya ilmu dan teknologi, penggunaan zat warna alami semakin berkurang dan digantikan dengan zat warna sintetik. Hal ini disebabkan bahan-bahan pewarna sintetik lebih murah dan memberikan warna yang lebih stabil apabila dibandingkan dengan pewarna alami [1].

Penambahan pewarna sintetik pada makanan sebenarnya bukanlah suatu larangan, namun apabila zat pewarna yang digunakan adalah pewarna yang tidak lazim untuk makanan, inilah yang membahayakan kesehatan. Untuk mengatasi permasalahan tersebut, maka perlu dilakukan penelitian untuk mencari alternatif bahan alam yang berpotensi dapat digunakan sebagai zat pewarna.

Salah satu sumber pigmen pewarna alami tersebut adalah kulit buah naga. Kulit buah naga berpotensi sebagai pewarna alami makanan karena menghasilkan warna merah yang dihasilkan oleh pigmen antosianin seperti cyanidin-3-sophoroside dan cyaniding-3-glucoside [2].

Beberapa penelitian tentang pemanfaatan kulit buah naga telah dilakukan. Wahyuni [3] memanfaatkan kulit buah naga super merah sebagai sumber antioksidan dan pewarna alami pada pembuatan jelly, Simanjuntak dkk [4] mengekstrak pigmen antosianin dari kulit buah naga merah dengan metode ekstraksi masearasi, Sudarmi dkk [5] melakukan ekstraksi sederhana antosianin dari kulit buah naga sebagai pewarna alami sedangkan Ingrath dkk [6] mengekstraksi pigmen antosianin dari kulit buah naga merah dengan menggunakan microwave. Berdasarkan penelitian yang telah dilakukan tersebut, masing-masing menggunakan bahan baku yang sama yaitu kulit buah naga namun perlakuan awal terhadap bahan baku tersebut tidaklah sama. Beberapa menggunakan bahan kering dan beberapa menggunakan bahan basah, serta ukuran standart bahan baku dan kecepatan pengadukan juga belum ada. 
Chemica

Volume 3, Nomor 2, Desember 2016, 39-45

ISSN: $2355-8776$

Pada penelitian ini, kulit buah naga merah yang akan diekstraksi diamati kadar airnya dan ukuran serbuknya. Selain itu juga dilakukan variasi kecepatan pengadukan selama proses ekstraksi. Sedangkan variabel suhu, waktu, dan pelarut mengacu pada kondisi optimum penelitian yang sudah pernah dilakukan. Analisis hasil dilakukan untuk mengetahui $\mathrm{pH}$, konsentrasi antosianin dan rendemen hasil. Antosianin yang diperoleh kemudian diujicobakan pada makanan. Penelitian ini bertujuan untuk mengetahui kondisi optimum pengambilan antosianin dari kulit buah naga merah dan pengaruh penambahan antosianin pada makanan.

Kulit buah naga merah memiliki kandungan nutrisi seperti karbohidrat, lemak, protein dan serat pangan. Kandungan serat pangan yang terdapat dalam kulit buah naga merah sekitar 46,7\% [7]. Ekstrak kulit buah naga merah mengandung antosianin 26,4587 ppm [8]. Antosianin merupakan zat warna yang berperan memberikan warna merah berpotensi menjadi pewarna alami untuk pangan dan dapat dijadikan alternatif pengganti pewarna sintetis yang lebih aman bagi kesehatan.

Ekstraksi adalah pemisahan suatu zat dari campurannya dengan pembagian sebuah zat terlarut antara dua pelarut yang tidak dapat tercampur untuk mengambil zat terlarut tersebut dari satu pelarut ke pelarut yang lain. Ekstraksi bertujuan untuk melarutkan senyawa-senyawa yang terdapat dalam jaringan tanaman ke dalam pelarut yang dipakai untuk proses ekstraksi tersebut. Proses ekstraksi bermula dari penggumpalan ekstrak dengan pelarut kemudian terjadi kontak antara bahan dan pelarut sehingga pada bidang datar antarmuka bahan ekstraksi dan pelarut terjadi pengendapan massa dengan cara difusi.

Spektrofotometri merupakan salah satu metode dalam kimia analisis yang digunakan untuk menentukan komposisi suatu sampel baik secara kuantitatif dan kualitatif yang didasarkan pada interaksi antara materi dengan cahaya. Peralatan yang digunakan dalam spektrofotometri disebut spektrofotometer. Cahaya yang dimaksud dapat berupa cahaya visible, UV dan inframerah, sedangkan materi dapat berupa atom dan molekul namun yang lebih berperan adalah electron valensi.

Absorbansi diukur tiap sampel pada $\lambda$ maks dan $\lambda 700 \mathrm{~nm}$. Distilat diuji absorbansinya dengan spektrofotometer UV-VIS pada panjang gelombang maksimum yaitu $520 \mathrm{~nm}$. Absorbansi dihitung dengan menggunakan persamaan (1).

$$
\mathrm{A}=\left(\lambda_{\text {maks }}-\lambda_{700}\right) \mathrm{pH} 1-\left(\lambda_{\text {maks }}-\lambda_{700}\right) \mathrm{pH} 4,5
$$

sedangkan kadar antosianin dihitung dengan persamaan 2 .

$$
\operatorname{Kadar} \operatorname{antosianin}(\mathrm{mg} / \mathrm{L})=\mathrm{A} \times \mathrm{BM} \times \mathrm{FP} \times 1000 / \varepsilon
$$

Keterangan [2]

$\varepsilon \quad=$ koefisien absorbivitas $26900 \mathrm{~L} / \mathrm{mol} . \mathrm{cm}^{-}$dinyatakan sebagai cyanidin-3-glucoside

$\mathrm{BM}=$ berat molekul cyanidin-3- glucoside $(449.2 \mathrm{~g} / \mathrm{mol})$

$\mathrm{FP}=$ faktor pengenceran

$\lambda_{\text {maks }}=$ serapan maksium sampel $(520 \mathrm{~nm})$

$\lambda_{700}=$ serapan cyanidin-3-glucoside

\section{Metodologi}

Bahan: kulit buah naga merah, larutan buffer $\mathrm{KCL} \mathrm{pH}$ 1, larutan buffer $\mathrm{CH}_{3} \mathrm{COONa} \mathrm{pH} 4,5$, ethanol 95\%, HCL $1 \%$, aquadest, terigu, gula putih, telur, pengembang kue, susu kental manis, margarin, dan pewarna merah (antosianin).

Alat: pisau, blender, ayakan, oven, timbangan digital, statis, kertas saring, corong, labu leher tiga, pendingin balik, pengaduk merkuri, thermometer, beaker glass, alat distilasi, $\mathrm{pH}$ meter, spektrofotometer, lak, penyumbat, dan kukusan roti.

\section{Cara Kerja:}

a. Menentukan kadar air optimum.

Kulit buah naga yang sudah dibersihkan, dikeringkan sampai kadar air 90\%, 70\%, 50\%, 30\%, dan 6\%. Masingmasing ditutup rapat dan dilakukan ekstraksi pada kondisi suhu $50{ }^{\circ} \mathrm{C}$, waktu 3 jam, perbandingan bahan:pelarut $=1: 11(\mathrm{HCl} 1 \%)$, kecepatan pengadukan $100 \mathrm{rpm}$. Analisa kadar antosianin, pH, absorbansi, dan rendemen.

b. Menentukan kecepatan pengadukan optimum.

Kulit buah naga dengan kadar air 6\% dan ukuran 40 mesh, diekstraksi dengan variasi kecepatan 100 rpm, 150 rpm, 200 rpm, 250 rpm, 300 rpm. Dengan kondisi variable lainnya sama seperti di atas. 
c. Menentukan ukuran optimum

Kulit buah naga dengan kadar air 6\% dibuat dalam berbagai ukuran, 20 mesh, 40 mesh, 60 mesh, 80 mesh, dan 100 mesh. Masing-masing diekstraksi pada kondisi sama seperti di atas pada kecepatan pengadukan $100 \mathrm{rpm}$.

d. Aplikasi antosianin sebagai zat warna makanan.

- Membuat adonan bolu kukus: Mencampur semua bahan roti (1 gelas terigu, 125 gram gula putih, 2 butir telur, setengah sendok teh pengembang kue, 3 sendok teh margarin, dan pewarna antosianin sesuai dengan variasi yang telah ditentukan.

- Antosianin yang sudah terbebas dari pelarutnya dan berbentuk serbuk tepung ditambahkan pada adonan di atas dengan variasi $0 \%, 1 \%, 3 \%$, dan $5 \%$. Kemudian dikukus menggunakan alat pengukus dan dilakukan uji organoleptik warna, rasa, dan aroma terhadap bolu kukus tersebut.

\section{Hasil dan Pembahasan}

\section{a. Percobaan untuk mendapatkan kondisi optimum}

Pengeringan yang paling efektif untuk mendapatkan kulit buah naga dengan kadar air rendah namun masih memiliki kadar antosianin yang relatif tinggi adalah menggunakan sinar matahari dengan memperhatikan kondisi kulit dan ukuran kulit tiap harinya. Ekstraksi pengambilan antosianin dari kulit buah naga yang sudah dikeringkan, dilakukan pada kondisi operasi optimum dari penelitian yang sudah pernah dilakukan, yaitu:

Gambar 1. menjelaskan bahwa semakin kecil kadar air yang terkandung di dalam kulit buah naga akan memberikan nilai absorbansi yang semakin tinggi. Hal ini dapat dijelaskan bahwa untuk mendapatkan kulit yang kering, dengan kadar air rendah akan memerlukan bahan baku kulit basah semakin banyak. Semakin rendah kadar airnya, semakin banyak kulit basah yang dibutuhkan. Sehingga semakin banyak juga antosianin yang terekstraksi. Hal ini juga berpengaruh terhadap rendemen dan kadar antosianin yang dapat terekstrak. Gambar 2. menunjukkan bahwa semakin rendah kadar air kulitnya, maka semakin tinggi nilai rendemen dan kadar antosianinnya.

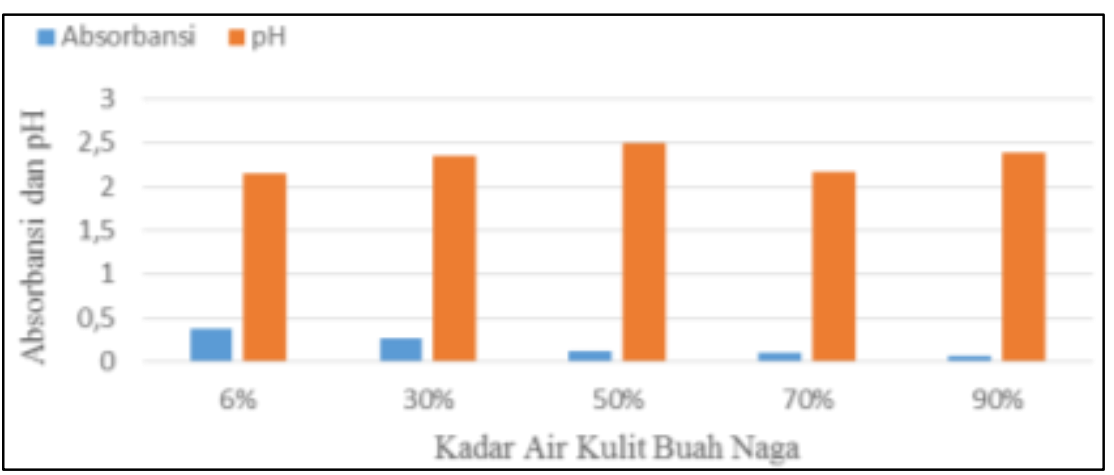

Gambar 1. Pengaruh Kadar Air Kulit Buah Naga terhadap Nilai Absorbansi dan pH pada Kondisi Putaran Pengaduk (N=100 rpm), Waktu ( $\mathrm{t}=3 \mathrm{jam})$, Perbandingan bahan : pelarut $(\mathrm{M}=1: 11 \mathrm{gr} / \mathrm{vol})$ dan Perbandingan Pelarut : $\mathrm{HCl}(\mathrm{Z}=9: 1)$

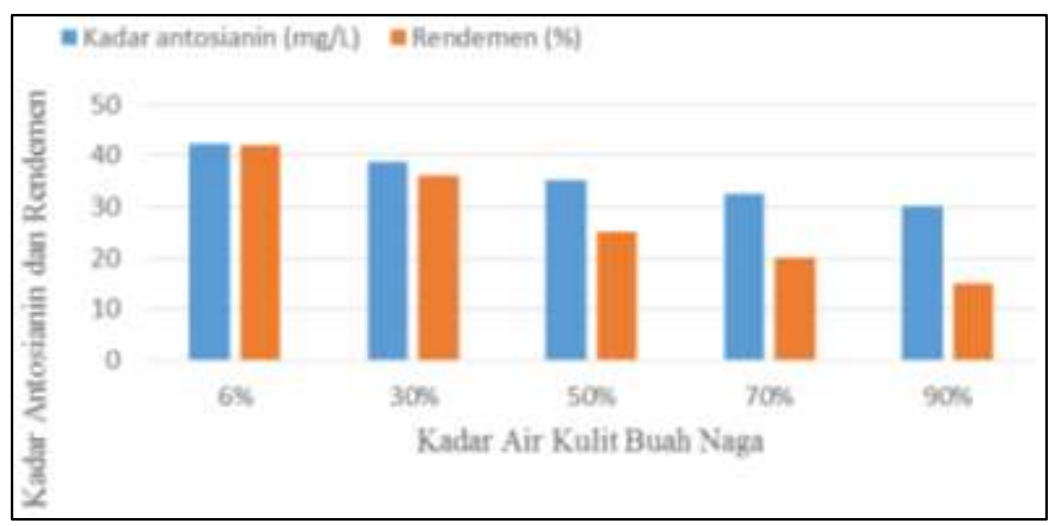

Gambar 2. Pengaruh Kadar Air Kulit Buah Naga terhadap Kadar Antosianin dan Rendemen pada Kondisi Putaran Pengaduk $(\mathrm{N}=100 \mathrm{rpm})$, Waktu ( $\mathrm{t}=3$ jam), Perbandingan Bahan : Pelarut $(\mathrm{M}=1: 11 \mathrm{gr} / \mathrm{vol})$ dan Perbandingan Pelarut $: \mathrm{HCl}(\mathrm{Z}=9: 1)$ 


\section{Chemica}

Volume 3, Nomor 2, Desember 2016, 39-45

ISSN: $2355-8776$

Gambar 1 juga menunjukkan bahwa seiring dengan penurunan $\mathrm{pH}$, nilai absorbansi akan meningkat. Hal ini karena antosianin akan lebih stabil pada $\mathrm{pH}$ yang rendah. Peningkatan nilai $\mathrm{pH}$ menunjukkan bahwa warna antosianin semakin memudar karena kation flavium yang berwarna merah mengalami hidrasi menjadi karbinol tidak berwarna. Hal ini disebabkan karena antosianin cepat rusak pada kondisi $\mathrm{pH}$ tinggi. Nilai pH yang fluktuatif pada gambar 1 karena pengaruh suhu yang naik turun saat proses ekstraksi.

Gambar 3 menunjukkan bahwa semakin cepat putaran pengadukan akan menyebabkan larutan semakin homogen. Kontak antara zat terlarut dengan pelarutnya akan menyebabkan terambilnya antosianin yang semakin besar. Reaksi akan menjadi lebih baik. Hal ini ditunjukkan juga dengan kadar antosianin dan rendemennya juga semakin tinggi.

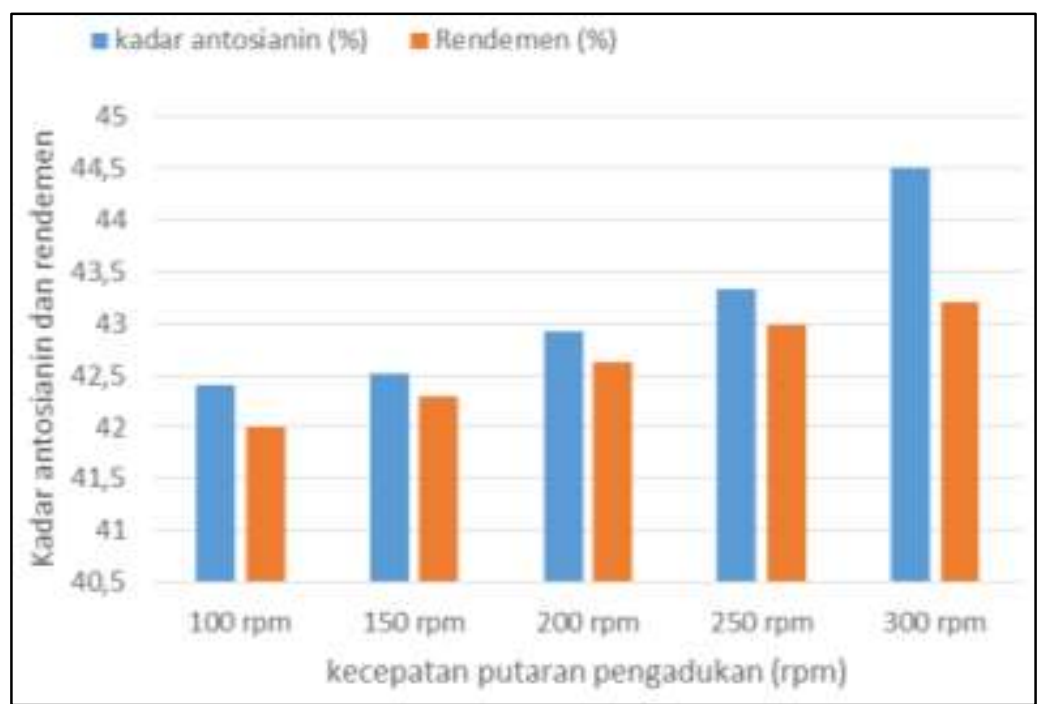

Gambar 3. Pengaruh Kecepatan Putaran Pengaduk pada Kadar Antosianin dan Rendemen Hasil pada Kadar Air 6\%, Ukuran 40 mesh, Waktu ( $\mathrm{t}=3$ jam), Perbandingan bahan : pelarut $(\mathrm{M}=1: 11 \mathrm{gr} / \mathrm{vol})$ dan Perbandingan Pelarut : $\mathrm{HCl}(\mathrm{Z}=9: 1)$

Pengaruh ukuran kulit buah naga yang diekstraksi dapat dilihat pada gambar 4. Gambar 4 menunjukkan semakin kecil ukuran kulit buah naga yang dinyatakan dengan meningkatnya angka mesh, akan memberikan nilai absorbansi yang semakin besar. Hal ini disebabkan karena ukuran kulit yang kecil (serbuk) akan memberi kemudahan pada jalannya proses ekstraksi. Dengan bantuan pengadukan, ukuran yang semakin kecil akan memudahkan pelarut dalam melarutkan zat warna antosianin yang terkandung.

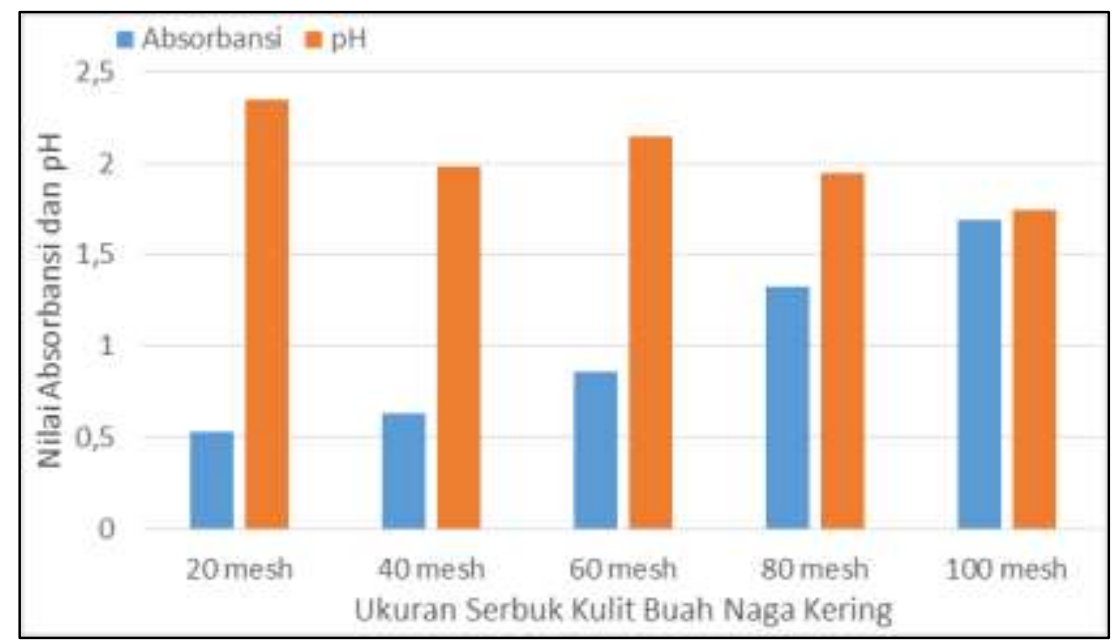

Gambar 4. Pengaruh Ukuran Kulit Buah Naga terhadap Nilai Absorbansi dan pH pada Kondisi Kadar Air 6\%, 200 rpm, Waktu ( $\mathrm{t}=3 \mathrm{jam})$, Perbandingan Bahan : Pelarut $(\mathrm{M}=1: 11 \mathrm{gr} / \mathrm{vol})$ dan Perbandingan Pelarut : $\mathrm{HCl}(\mathrm{Z}=9: 1)$ 


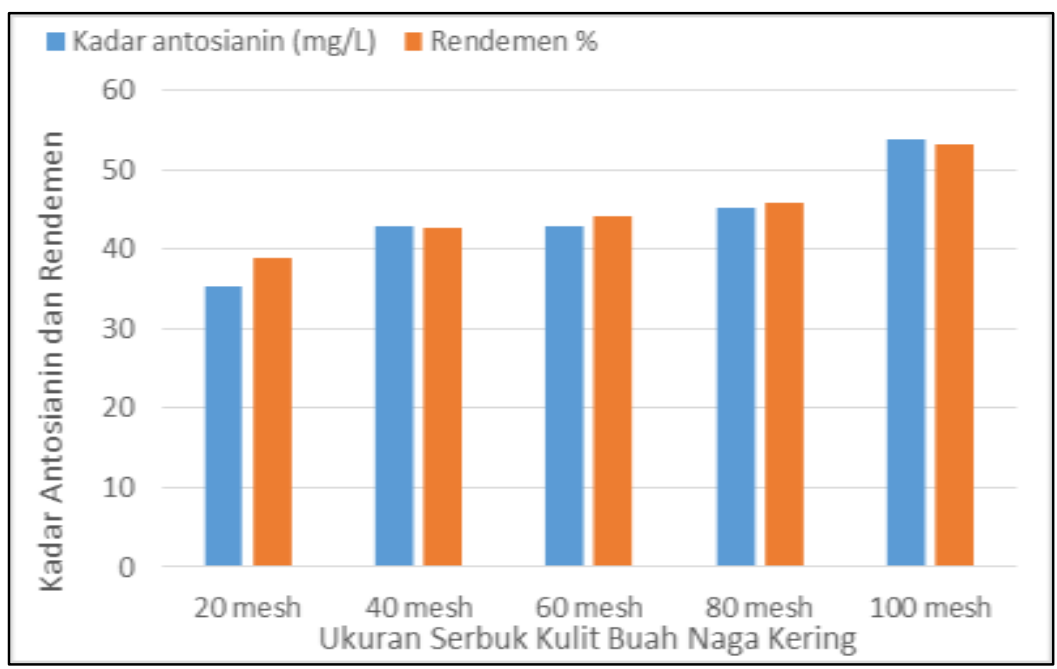

Gambar 5. Pengaruh Ukuran Kulit Buah Naga terhadap Kadar Antosianin dan Rendemen Hasil pada Kondisi Kadar Air $6 \%$, $200 \mathrm{rpm}$, Waktu (t=3 jam), Perbandingan bahan : pelarut (M=1:11 gr/vol) dan Perbandingan Pelarut : $\mathrm{HCl}(\mathrm{Z}=9: 1)$

Pencarian ukuran optimum untuk kulit buah naga kering dihentikan pada ukuran 100 mesh, karena ukuran ini sudah sangat kecil bagi serbuk kulit kering buah naga merah.

Percobaan zat warna antosianin pada makanan dicobakan pada pembuatan bolu kukus. Bolu kukus yang dibuat berbahan dasar susu, gula, telur dan terigu. Rasa yang dominan pada bolu kukus ini rasa manis dan gurihnya aroma susu. Percobaan dilakukan pada proses pembuatan bolu kukus dengan variasi kondisi:

a.Tanpa penambahan antosianin kulit buah naga merah

b.Penambahan antosianin kulit buah naga merah $1 \%$

c.Penambahan antosianin kulit buah naga merah $3 \%$

d.Penambahan antosianin kulit buah naga merah 5\%

\section{b. Penilaian Organoleptik}

Warna: Penambahan kulit buah naga merah berpengaruh nyata terhadap warna bolu kukus yang dihasilkan baik secara uji deskriptif maupun uji hedonik. Rata-rata hasil penilaian organoleptik secara deskriptif dan hedonik tercantum pada tabel 1.

Tabel 1. Rata-rata penilaian uji deskriptif dan uji hedonik terhadap warna bolu kukus kulit buah naga merah

\begin{tabular}{ccc}
\hline \multirow{2}{*}{ Perlakuan } & \multicolumn{2}{c}{ Rata-rata } \\
\cline { 2 - 3 } & Deskrptif & Hedonik \\
\hline (Tanpa penambahan antosianin kulit buah naga merah) & $1,67^{\mathrm{a}}$ & $3,25^{\mathrm{a}}$ \\
(Penambahan antosianin kulit buah naga merah 1\%) & $3,10^{\mathrm{b}}$ & $3,20^{\mathrm{a}}$ \\
(Penambahan antosianin kulit buah naga merah 3\%) & $3,57^{\mathrm{c}}$ & $3,55^{\mathrm{ab}}$ \\
(Penambahan antosianin kulit buah naga merah 5\%) & $4,57^{\mathrm{d}}$ & $3,90^{\mathrm{b}}$ \\
\hline
\end{tabular}

Ket: Angka-angka yang diikuti oleh huruf kecil yang berbeda menunjukkan berbeda nyata. Skor deskriptif 5: sangat merah; 4: merah; 3: merah muda; 2: putih; 1: sangat putih dan Skor hedonik 5: sangat suka; 4: suka; 3: agak suka; 2: tidak suka; 1: sangat tidak suka.

Tabel 1 menunjukkan rata-rata penilaian para panelis terhadap uji deskriptif dan uji hedonik mengalami peningkatan seiring dengan penambahan antosianin kulit buah naga merah di dalam adonan bolu kukus. Apabila dilihat dari sisi deskriptifnya, warna merah akan diperoleh pada penambahan antosianin kulit buah naga merah sebanyak 5\%. Semakin banyak antosianin kulit buah naga merah yang ditambahkan, akan semakin merah warna bolu kukus yang dihasilkan. 
Chemica

Volume 3, Nomor 2, Desember 2016, 39-45

ISSN: $2355-8776$

Uji organoleptik dari sisi hedonic menunjukkan bahwa penambahan antrosianin kulit buah naga merah tidak berpengaruh terhadap rasa bolu kukus yang dihasilkan. Para panelis masih menyatakan bahwa bolu kukus tersebut enak walaupun ditambahkan antosianin kulit buah naga sebanyak 5\%.

Rasa: Penambahan antosianin kulit buah naga merah pada pembuatan bolu kukus tidak berpengaruh terhadap perubahan rasanya. Bolu kukus yang terbuat dari telur, susu, gula, air dan terigu akan tetap memberikan rasa manis dan gurih walaupun kedalam adonannya ditambah zat warna antosianin kulit buah naga merah. Hal ini dapat dilihat pada tabel 2 sebagai berikut:

Tabel 2. Rata-rata penilaian uji deskriptif dan uji hedonik terhadap rasa bolu kukus kulit buah naga merah

\begin{tabular}{lcc}
\hline \multirow{2}{*}{ Perlakuan } & \multicolumn{2}{c}{ Rata-rata } \\
\cline { 2 - 3 } & Deskrptif & Hedonik \\
\hline (Tanpa penambahan antosianin kulit buah naga merah) & 4,15 & 3,65 \\
(Penambahan antosianin kulit buah naga merah 1\%) & 4,20 & 3,78 \\
(Penambahan antosianin kulit buah naga merah 3\%) & 4,05 & 3,99 \\
(Penambahan antosianin kulit buah naga merah 5\%) & 3,98 & 4,08 \\
\hline
\end{tabular}

Ket: Angka-angka yang diikuti oleh huruf kecil yang berbeda menunjukkan berbeda nyata. kor deskriptif 5: sangat manis; 4: manis; 3: agak manis; 2: tidak manis; 1: sangat tidak manis dan Skor hedonik 5: sangat suka; 4: suka; 3: agak suka; 2: tidak suka; 1: sangat tidak suka.

Para panelis menyatakan suka terhadap rasa bolu kukus yang tanpa penambahan antosianin ataupun yang dengan penambahan antosianin kulit buah naga merah. Hal ini ditunjukkan dengan hasil uji hedonic berkisar antara $3,65-4,08$. Rasa pada bolu kukus yang dihasilkan sangat dipengaruhi oleh rasa manis gula dan gurihnya susu.

Aroma: Berdasarkan hasil uji deskriptif bolu kukus dengan penambahan antosianin kulit buah naga merah tidak berpengaruh nyata terhadap aroma susu yang dominan. Hal ini dapat ditunjukkan pada tabel 3 .

Tabel 3. Rata-rata penilaian uji deskriptif dan uji hedonik terhadap aroma bolu kukus kulit buah naga merah

\begin{tabular}{ccc}
\hline \multirow{2}{*}{ Perlakuan } & \multicolumn{2}{c}{ Rata-rata } \\
\cline { 2 - 3 } & Deskrptif & Hedonik \\
\hline (Tanpa penambahan antosianin kulit buah naga merah) & 4,58 & 3,56 \\
(Penambahan antosianin kulit buah naga merah 1\%) & 4,05 & 3,79 \\
(Penambahan antosianin kulit buah naga merah 3\%) & 4,00 & 3,70 \\
(Penambahan antosianin kulit buah naga merah 5\%) & 4,15 & 3,45 \\
\hline
\end{tabular}

Ket: Skor deskriptif 5: aroma susu sangat jelas; 4: aroma susu jelas; 3: aroma susu agak jelas; 2: tidak beraroma susu; 1: sangat tidak beraroma susu dan Skor hedonik 5: sangat suka; 4: suka; 3: agak suka; 2: tidak suka; 1: sangat tidak suka.

Penambahan kulit buah naga merah berpengaruh nyata terhadap warna bolu kukus yang dihasilkan baik secara uji deskriptif maupun uji hedonic. Penilaian para panelis terhadap uji deskriptif dan uji hedonik mengalami peningkatan seiring dengan penambahan antosianin kulit buah naga merah di dalam adonan bolu kukus. Apabila dilihat dari sisi deskriptifnya, warna merah akan diperoleh pada penambahan antosianin kulit buah naga merah sebanyak 5\%. Semakin banyak antosianin kulit buah naga merah yang ditambahkan, akan semakin merah warna bolu kukus yang dihasilkan.

Uji organoleptik dari sisi hedonic menunjukkan bahwa penambahan antrosianin kulit buah naga merah tidak berpengaruh terhadap rasa bolu kukus yang dihasilkan. Para panelis masih menyatakan bahwa bolu kukus tersebut enak walaupun ditambahkan antosianin kulit buah naga sebanyak 5\%.

Penambahan antosianin kulit buah naga merah pada pembuatan bolu kukus tidak berpengaruh terhadap perubahan rasanya. Bolu kukus yang terbuat dari telur, susu, gula, air dan terigu akan tetap memberikan rasa manis dan gurih walaupun kedalam adonannya ditambah zat warna antosianin kulit buah naga merah.

Penambahan antosianin kulit buah naga merah sampai kadar $5 \%$ masih mempertahankan aroma susu yang khas pada bolu kukus yang dihasilkan. Hal ini agak berbeda dengan penelitian yang telah dilakukan oleh Waladi [9]. Waladi menyatakan bahwa penambahan bubur kulit buah naga merah mempengaruhi aroma susu yang terdapat dalam es krim. Semakin banyak bubur kulit buah naga yang ditambahkan, aroma akan menjadi agak langu. Hal ini 
disebabkan karena pada penelitian yang dilakukan Waladi [9] menggunakan bubur kulit buah naga, sedangkan pada penelitian ini menggunakan antosianin yang sudah bebas dari pelarutnya dan berupa serbuk tepung antosianin.

Dengan memanfaatkan limbah kulit buah naga merah ini, diharapkan dapat mengurangi pemakaian zat warna sintesis. Pemanfaatan kulit buah naga merah sebagai zat warna, dapat secara langsung dengan membuat bubur kulit buah naga merah ataupun dengan mengekstrak zat warna antosianinnya terlebih dahulu.

\section{Kesimpulan}

Kulit buah naga merah mengandung antosianin yang dapat dimanfaatkan sebagai zat warna alami. Semakin kecil kadar air dan semakin kecil ukuran butir kulit buah naga, maka kadar antosianinnya akan semakin tinggi. Putaran pengaduk yang semakin cepat menyebabkan homogenitas larutas cepat tercapai, akan meningkatkan nilai rendemen dan kadar antosianin yang dihasilkan.

Proses ekstraksi untuk mengambil antosianin yang terlarut akan berjalan optimal apabila kadar air yang terkandung di dalam kulit sedikit, memiliki ukuran kulit yang kecil, dan menggunakan kecepatan pengadukan yang tinggi. Kondisi optimum yang diperoleh pada penelitian ini adalah kadar air kulit buah naga 6\%, ukuran butir kulit kering 100 mesh dan kecepatan pengadukan $300 \mathrm{rpm}$.

Uji organoleptik antosianin yang terkandung dalam kulit buah naga merah terhadap nilai warna, rasa, dan aroma dapat disimpulkan bahwa antosianin yang diperoleh memberikan warna yang sesuai dan tidak berpengaruh nyata terhadap rasa dan aroma.

\section{Daftar Notasi}

$\mathrm{N} \quad=$ kecepatan putaran pengadukan, rpm

$\mathrm{t} \quad=$ waktu ekstraksi, jam

$\mathrm{M} \quad=$ perbandingan serbuk kulit dan pelarut, gram/vol

$\mathrm{z}=$ perbandingan pelarut $\mathrm{dan} \mathrm{HCl}, \mathrm{vol} / \mathrm{vol}$

\section{Daftar Pustaka}

[1]. Lazuardi, R.N.M., 2010, Mempelajari Ekstraksi Pigmen Antosianin dari Kulit Manggis (Garcinia mangostana L) dengan berbagai Jenis Pelarut, Tugas Akhir Jurusan Teknik Pangan Fakultas Teknik, Universitas Pasundan, Bandung.

[2]. Wrolstad, R. E. and Giusti, M. M., 2001, Characterization and Measurement of Anthocyanin by UV-Visible Spectroscopy: Current Protocols in Food Analytical Chemistry, John Wiley and Son, New York.

[3]. Wahyuni, R., 2011, Pemanfaatan Kulit Buah Naga Super Merah (Hylocereaus polyrhizus) sebagai Sumber Antioksidan dan Pewarna Alami pada Pembuatan Jelly, Jurnal Teknologi Pangan, Fakultas Pertanian Universitas Yudharta Pasuruan, Vol. 2 No.1.

[4]. Simanjuntak, L., Sinaga, C., Fatimah, 2014, Ekstraksi Antosianin dari Kulit Buah Naga Merah (Hylocereus polyrhizus), Jurnal Teknik Kimia USU, Vol.3, No.2.

[5]. Sudarmi, S., Subagyo, P., Susanti, A., 2015, Wahyuningsih, A.S., Ekstraksi Sederhana Antosianin dari Kulit Buah Naga (Hylocereaus polyrhizus) sebagai Pewarna Alami. Jurnal Eksergi, Vol. XII, No. 01.

[6]. Ingrath, W., Nugroho, W.A., Yulianingsih, R., 2015, Ekstraksi Pigmen Antosianin dari Kulit Buah Naga Merah (Hylocereus costaricensis) sebagai Pewarna Alami Makanan dengan Menggunakan Microwave (Kajian Waktu Pemanasan dengan Microwave dan Penambahan Rasio Pelarut Aquades dan Asam Sitrat), Jurnal Bioproses Komoditas Tropis, Fakultas Teknologi Pertanian Universitas Brawijaya, Vol. 3, No. 3

[7]. Saneto, B., 2005, Karakterisasi Kulit Buah Naga Merah (Hylocereus polyrizus), Jurnal Agarika, Vol.2, 143149.

[8]. Citramukti, I., 2008, Ekstraksi dan Uji Kualitas Pigmen Antosianin pada Kulit Buah Naga Merah (Hylocereus polyrhizus), Skripsi Jurusan Teknologi Hasil Pertanian, Fakultas Pertanian Universitas Muhammadiyah Malang, Malang.

[9]. Waladi, dkk, 2015, Penambahan Kulit Buah Naga Merah (Hylocereaus polyrhizus.) Sebagai Bahan Tambahan Dalam Pembuatan Es Krim, Jurnal Jom Faperta Vol.2 No.1. 